\title{
Vermiremediation and Mycoremediation of Polycyclic Aromatic Hydrocarbons in Soil and Sewage Sludge Mixture: A Comparative Study
}

\author{
A. B. Azizi, K. Y. Liew, Z. M. Noor, and Noorlidah Abdullah
}

\begin{abstract}
Polycyclic aromatic hydrocarbons-contaminated soil and sewage sludge mixtures in microcosms were tested separately in triplicate with two types of biological agents, namely earthworms (Lumbricus rubellus) and spent fungal mycelia of Pleurotus sajor-caju (SPC) for 60 days. The results indicated that vermiremediation (VMR) and mycoremediation (MYC) showed degradation result of $99.99 \%$ PAHs i.e. Anth, Phen and BaP removal. Ten earthworms and $750 \mathrm{~g}$ of SPC depicted optimum results in nutrient element content among respective treatments. Treatment of MYC resulted a consistence increment of soil macronutrients except for TP and TKN (500 g treatment) compared to VMR. Hence, sixty days incubation of spent fungal mycelia of Pleurotus sajor-caju compost (SPC) is potential to degrade $\mathbf{9 9 . 9 9 \%}$ of Anth, Phen and $\mathrm{BaP}$ but at the same time enrich the soil macronutrients i.e. TOC, TKN and TK.
\end{abstract}

Index Terms-Bioremediation, lumbricus rubellus, spent mushroom compost, vermitechnology.

\section{INTRODUCTION}

Polycyclic aromatic hydrocarbons or polynuclear aromatic hydrocarbons (PAHs) are chemical compounds made up of more than two fused aromatic rings in a linear or clustered arrangement, usually containing only carbon (C) and hydrogen $(\mathrm{H})$ atoms, although nitrogen $(\mathrm{N})$, sulphur $(\mathrm{S})$ and oxygen $(\mathrm{O})$ atoms may readily substitute in the benzene ring to form heterocyclic aromatic compounds [1]. PAHs originate from pyrogenic, petrogenic and natural sources; the former two are the major anthropogenic sources of PAHs in the environment [2]. Pyrogenic sources coming from incomplete combustion of organic matters such as fossil fuels and wood whereas petrogenic sources originated from crude oil and petroleum products [3]. Pyrogenic PAHs are released into the atmosphere as gasses and soot particles [4]. They are transported onto land through wet and dry deposition. Petrogenic PAHs are released through oil spills, leaking of engine and fuel oil, dumping of used crankcase oil and

Manuscript received March 4, 2013; revised May 8, 2013. This work was financially supported by the Exploratory Research Grant Scheme (ER019-2011A) from Ministry of Higher Education Malaysia and partly by University of Malaya Research Grant (RG007-09AFR) supplemented with PPP grant (PS272-2010B) managed by Advanced Fundamental Research (AFR) Cluster UM.

A. B. Azizi is with the UM-Kyoto University Program under Sustainability Science (SuSci) Research Cluster, Research Management \& Innovation Complex (RMIC), University of Malaya 50603 Kuala Lumpur (e-mail: azieaxis@gmail.com, azizi.bkr@um.edu.my).

K. Y. Liew, Z. M. Noor and Noorlidah Abdullah are with the Institute of Biological Sciences, Faculty of Science, University of Malaya 50603 Kuala Lumpur (e-mail: janice_hirokikonishi@hotmail.com, alin@um.edu.my, noorlidah@um.edu.my). unburned fuel absorbed into street dust [4].

Research on the potential utilisation of earthworms has shown an ability to manage polluted land and even sewage sludge, which is termed as vermicomposting or vermistabilisation. In its basic form, this is a low-cost technology system that primarily uses earthworms in the processing or treatment of organic wastes. In this field, application of Lumbricus rubellus is scarce compare to Eisenia foetida. Apart from the role of earthworms in bioremediation, white-rot fungi also potential in producing extracellular enzymes, which degrade PAHs. Similar scenario reported for Pleurotus sajor-caju, which not commonly tested on its ability to degrade persistence organic pollutants.

Therefore, the objective of the study is to compare the potential of L. rubellus and spent $P$. sajor-caju compost (SPC) in polycyclic aromatic hydrocarbons (PAHs) viz. Anth, Phen and $\mathrm{BaP}$ biodegradation and the nutrient elements content in the soil and sewage sludge (SS) mixture after treatment.

\section{MATERIALS AND METHODS}

\section{A. Preparation of Bioremediation Agents}

The earthworms were obtained from a vermicomposting farm in Ijok, Selangor and reared in the Earthworms Reservoir, Institute of Biological Sciences (ISB), University of Malaya. Before the earthworm was selected as a bioremediation agent, vermiculture commenced and the worms were cultured in SS for one month; only clitelated earthworms were taken as the agent before being introduced to the treatment microcosms. SPC as a feed material (bulking agent) was mixed together with SS for culturing in a ratio of 20:80 (SS: SMC). Before the culture started, the mixed substrate was pre-composted for 21 days. This was to ensure that non-thermophilic and non-pathogenic conditions occurred when the earthworms introduced to the culturing substrates. The temperature was maintained at $27 \pm 1^{\circ} \mathrm{C}, \mathrm{pH}$ was $7 \pm 1$ and moisture content was $70 \pm 10 \%$. The treatment was monitored once a week by sprinkling distilled water using wash bottles ( $80-160 \mathrm{~m} \ell$ per microcosm) for moisture content maintenance, temperature stabilisation and $\mathrm{pH}$ control.

SPC was taken from a mushroom cultivation farm in Tanjung Sepat, Selangor, which produces more than a tonne per day. Six-month old P. sajor-caju grown on sawdust substrate in plastic bags was discarded after 4-5 harvests. These bags weighed $\sim 600 \mathrm{~g}$ each, and were usually dumped or burnt in the farm.

Garden organic soils were purchased from the market with 
$4.2 \mathrm{~kg}$ per packet, as a mixture of soil and humus. Clay, silt and sand percentages were calculated. Sewage sludge (SS) was taken from Bunus STP in Titiwangsa, Kuala Lumpur. SS

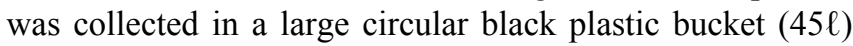
and non-biodegradable particles such as rubber band, plastics, metal pieces, glass pieces, chewing gum etc. were removed after the collection. PAHs, i.e. Anth, Phen and BaP, were purchased as follows:

$\begin{aligned} \text { i. } & \text { anthracene (Sigma-Aldrich C/N: A89200) } \\ \text { ii. } & \text { phenanthrene (Sigma-Aldrich C/N: 77472) } \\ \text { iii. } & \text { benzo }(\alpha) \text { pyrene (Sigma-Aldrich C/N: B1760) }\end{aligned}$

Microcosm; a plastic container with a size of $360 \mathrm{~mm} \times$ $280 \mathrm{~mm} \times 200 \mathrm{~mm}$ (length $\times$ width $\times$ height) was designed with an aperture size of $250 \mathrm{~mm} \times 100 \mathrm{~mm}$ on lid covered with net at the centre to prevent intervention from pests. This was to give aeration for aerobic species and microclimatic conditions for treatment [5], [6].

\section{B. Experimental Design}

The soil was primed in a microcosm with $1 \mathrm{~kg}$ for each replicate and it was applied to all treatments. The soil mixed with SS by manual turning was prepared with ratio of 10:1 (soil:SS) and PAHs were artificially inserted in the soil and SS mixture at each treatment by weight (Anth $500 \mathrm{mg} \mathrm{kg}^{-1}$, Phen $100 \mathrm{mg} \mathrm{kg}^{-1}$ and $\mathrm{BaP} 50 \mathrm{mg} \mathrm{kg}^{-1}$ ) using an electronic balance.

The vermiremediation (VMR) process utilised earthworms L. rubellus species; three treatments were tested in the process: 10, 30 and 50 earthworms were introduced to the contaminated mixture. Culturing in the contaminated mixture tested the earthworms and only clitelated earthworms were selected from the vermiculture for the treatment process.

The mycoremediation (MYC) process involved three treatments: $250 \mathrm{~g}, 500 \mathrm{~g}$ and $750 \mathrm{~g}$ of the spent $P$. sajor-caju compost (SPC) was introduced to the contaminated mixture. Each treatment was done in triplicate. The moisture content was maintained at $70 \pm 10 \%$ using distilled water, temperature $27 \pm 1^{\circ} \mathrm{C}, \mathrm{pH} 7 \pm 1$ (these parameters applied to all treatments).

\section{Laboratory Analysis}

Approximately $50 \mathrm{~g}$ of soil mixture from all treatments was sampled for laboratory analysis after the allotted time set for all treatments. The PAHs were analysed using Gas Chromatography-Mass Spectrometry (GCMS). ASTM E 949 determined total Organic Carbon (TOC). Total Kjeldahl nitrogen (TKN) was estimated by ASTM E 778. ASTM D 5198 detected total Phosphorus (TP). Total Potassium (TK) was measured using ASTM E 926.

\section{Statistical Analysis}

Data were analysed for significant differences $(P<0.05)$ between treatments using one-way analysis of variance (ANOVA) for concentrations of Phen, Anth and BaP using SPSS for Windows version 16.0 (SPSS, Inc., Chicago, IL, USA).

\section{RESUlTS AND DisCUSSION}

\section{A. Vermiremediation (VMR)}

Identical results were illustrated for Anth and Phen in all treatments and control at day 30 and $60\left(<2.00 \mu \mathrm{g} \mathrm{kg}^{-1}\right)$; the same trend was seen for $\mathrm{BaP}\left(<5.00 \mu \mathrm{g} \mathrm{kg}^{-1}\right)$ (Table I). The results implied removal of $99.99 \%$ of PAHs compared to the day 0 concentrations viz. Anth $500 \mathrm{mg} \mathrm{kg}^{-1}$, Phen $100 \mathrm{mg} \mathrm{kg}^{-1}$ and $\mathrm{BaP} 50 \mathrm{mg} \mathrm{kg}^{-1}$. A similar pattern of degradation was found for all treatments at day 30 and day 60, the PAHs i.e. Anth, Phen and $\mathrm{BaP}$ resulted in the removal of $99.99 \%$ during the analysis period. This finding is in agreement with [7], who recorded the removal of Anth, Phen and $\mathrm{BaP}$ in soil with the presence of earthworms i.e. Eisenia foetida with $51 \%$ removal for Anth, 100\% for Phen and 47\% for BaP.

The nutrient contents i.e. TKN, TP and TK of the soil, particularly TKN, at day 30 were comparatively higher than at day 60 (Table II; Table III). Among the day 30 results, the 10 -earthworms treatment showed high nutrients content compared to other treatments. Statistical analysis of one-way ANOVA showed no significant differences in nutrient elements for all treatments $(P>0.05)$ at day 30, whilst at day 60 only TK showed a significant difference $(P<0.05 ; d f=2$; $F=6.814)$. N might originate from the addition of $\mathrm{N}$ by the earthworm itself in the form of mucus, nitrogenous excretory substances, growth-stimulating hormones and enzymes [8]. The results of $\mathrm{P}$ and $\mathrm{K}$ content were probably due to the direct action of the earthworm gut enzymes and indirectly by stimulation of the microflora. Removal of PAHs is related to the nutrient content as the earthworms excrete nutrients such as $\mathrm{N}$ and $\mathrm{P}$ in their casts, as well as to the presence of microorganisms, which possibly accelerate the removal of PAHs [9], [10].

TABLE I: PAHS CONTENT IN TREATMENTS OF VERMIREMEDIATION AND MYCOREMEDIATION AT DAY 30 AND 60

\begin{tabular}{llll}
\hline \hline Treatment & Anth $\left(\mu \mathrm{g} \mathrm{kg}^{-1}\right)$ & Phen $\left(\mu \mathrm{gg}^{-1}\right)$ & $\mathrm{B}(\mathrm{a}) \mathrm{P}\left(\mu \mathrm{g} \mathrm{kg}^{-1}\right)$ \\
\hline T10/250 & $\mathrm{ND}(<2.00)$ & $\mathrm{ND}(<2.00)$ & $\mathrm{ND}(<5.00)$ \\
T30/500 & $\mathrm{ND}(<2.00)$ & $\mathrm{ND}(<2.00)$ & $\mathrm{ND}(<5.00)$ \\
T50/750 & $\mathrm{ND}(<2.00)$ & $\mathrm{ND}(<2.00)$ & $\mathrm{ND}(<5.00)$ \\
\hline
\end{tabular}

T: Treatment; ND: not detected; T10/250: 10 earthworms / $250 \mathrm{~g}$ of SPC; T30/500: 30 earthworms / $500 \mathrm{~g}$ of SPC; T50/750: 50 earthworms / $750 \mathrm{~g}$ of SPC.

TABLE II: NUTRIENT ELEMENTS CONTENT IN VMR ON DAY 30

\begin{tabular}{lllll}
\hline \hline Treatment & TOC & TKN & TP & TK \\
\hline 10 earthworms & $0.50 \pm 0.22$ & $0.69 \pm 0.03$ & $0.16 \pm 0.02$ & $0.44 \pm 0.05$ \\
30 earthworms & $0.20 \pm 0.03$ & $0.58 \pm 0.04$ & $0.16 \pm 0.01$ & $0.46 \pm 0.02$ \\
50 earthworms & $0.40 \pm 0.09$ & $0.61 \pm 0.07$ & $0.13 \pm 0.02$ & $0.29 \pm 0.03$ \\
\hline
\end{tabular}

Value are means and standard error (mean \pm S.E.M; $n=3$ )

TABLE III: NUTRIENT ELEMENTS CONTENT IN VMR ON DAY 60

\begin{tabular}{lllll}
\hline \hline Treatment & TOC & TKN & TP & TK \\
\hline 10 earthworms & $0.57 \pm 0.03$ & $0.49 \pm 0.04$ & $0.19 \pm 0.01$ & $0.57 \pm 0.04$ \\
30 earthworms & $0.27 \pm 0.12$ & $0.38 \pm 0.07$ & $0.14 \pm 0.03$ & $0.44 \pm 0.10$ \\
50 earthworms & $0.43 \pm 0.23$ & $0.42 \pm 0.04$ & $0.21 \pm 0.03$ & $0.38 \pm 0.03$ \\
\hline
\end{tabular}

Value are means and standard error (mean \pm S.E.M; $\mathrm{n}=3$ )

\section{B. Mycoremediation (MYC)}

Similar degradation results to vermiremediation were obtained in mycoremediation (Table I). The removal of Anth, Phen and $\mathrm{BaP}$ by $99.99 \%$ within 30 days was highest compared to reported work by [11], Trametes versicolor was 
able to remove PAHs in sterile soil by $50 \%$ after 10 weeks of treatment and Irpex lacteus removed PAHs by $27 \%$ after the same duration. The degradation of the PAHs was due to the enzymatic actions produced by the remnant mycelia of $P$. sajor-caju utilised in this treatment even though this requires further analysis.

Nutrient content recorded the increment on day 60 compared to day 30 except for TKN in $500 \mathrm{~g}$ of SPC and all treatments in TP (Table IV; Table V). The highest content of TOC and TK is in $750 \mathrm{~g}$ treatment at day 60 compared to day 30. Whereas, for TKN and TP content the highest in $250 \mathrm{~g}$ (day 60) and $250 \mathrm{~g}$ (day 30) treatments. Statistical analysis of one-way ANOVA showed that no significant differences were seen for nutrient elements in all treatments $(P>0.05)$ at both day 30 and day 60 . The increment of TOC indicates the availability of the carbon supplements in order to sustain microbial community to degrade PAHs. Thus, additional carbon supplies are not required in this study because results shown dramatic degradation of PAHs within the incubation period and it was without extra carbon supplement. Increment of TKN postulates that biostimulation of electron acceptor primarily used for microbial cellular growth $\left(\mathrm{NH}_{4}{ }^{+}\right.$ or $\mathrm{NO}_{3}^{-}$) is not require to assist indigenous microbial assimilation. Decrease in TP on day 60 might be due to consumption of the indigenous microbial communities for cellular growth to enhance the PAHs degradation in the microcosms. Increment of TK was the effect of mineralisation resulted from enhanced microbial and enzymes' activities as part of the degradation of PAHs.

TABLE IV: NUTRIENT ELEMENTS CONTENT IN MYC ON DAY 30

\begin{tabular}{lllll}
\hline \hline Treatment & TOC & TKN & TP & TK \\
\hline $250 \mathrm{~g}$ & $0.40 \pm 0.06$ & $0.33 \pm 0.05$ & $0.18 \pm 0.03$ & $0.42 \pm 0.10$ \\
$500 \mathrm{~g}$ & $0.27 \pm 0.17$ & $0.45 \pm 0.06$ & $0.15 \pm 0.01$ & $0.35 \pm 0.02$ \\
$750 \mathrm{~g}$ & $0.53 \pm 0.38$ & $0.33 \pm 0.05$ & $0.16 \pm 0.05$ & $0.38 \pm 0.04$ \\
\hline \multicolumn{5}{l}{ Value are means and standard error (mean \pm S.E.M; $\mathrm{n}=3)$}
\end{tabular}

TABLE V: NUTRIENT ELEMENTS CONTENT IN MYC ON DAY 60

\begin{tabular}{lllll}
\hline \hline Treatment & TOC & TKN & TP & TK \\
\hline $250 \mathrm{~g}$ & $0.83 \pm 0.15$ & $0.50 \pm 0.13$ & $0.13 \pm 0.03$ & $0.48 \pm 0.04$ \\
$500 \mathrm{~g}$ & $2.53 \pm 0.87$ & $0.26 \pm 0.05$ & $0.14 \pm 0.01$ & $0.46 \pm 0.04$ \\
$750 \mathrm{~g}$ & $0.87 \pm 0.09$ & $0.41 \pm 0.10$ & $0.13 \pm 0.01$ & $0.50 \pm 0.04$ \\
\hline \multicolumn{5}{l}{ Value are means and standard error (mean \pm S.E.M; $\mathrm{n}=3)$} \\
\hline \hline
\end{tabular}

\section{Comparison between VMR and MYC}

There is no difference in the effects of PAHs degradation in soil and SS mixture since both of the treatments resulted similar content of PAHs after the incubation period. Nutrient elements content has shown a comparable result between the two bioremediation techniques. VMR only showed increment in all treatments for TOC on day 60 compared to day 30. The other soil macronutrients in VMR reflected inconsistence of soil nutrients content between treatments. On the other hand, MYC showed consistence increment of soil nutrient content between day 30 and 60 except for TP and TKN (500 g treatment). These results indicate L. rubellus as macroinvertebrate consumed much of the nutrients available to meet its dietary uptake. Whereas in MYC, spent fungal mycelia of $P$. sajor-caju incorporates with indigenous microbes community to degrade PAHs and enriching the soil macronutrients' content.

\section{CONCLUSION}

Vermiremediation utilising L. rubellus and mycoremediation using spent $P$. sajor-caju compost has proved its potential to degrade polycyclic aromatic hydrocarbons i.e. Anth, Phen and $\mathrm{BaP}$ in 30 days of incubation. These treatments can be further tested in pilot scale or in-situ in order to study its ability at on-site environmental contamination.

\section{ACKNOWLEDGMENT}

The authors are thankful to Indah Water Konsortium Sdn. Bhd. and Ganofarm Sdn. Bhd. for the sewage sludge and spent mushroom compost supplies, respectively.

\section{REFERENCES}

[1] S. Gan, E. V. Lau, and H. K. Ng, "Remediation of soils contaminated with polycyclic aromatic hydrocarbons (PAHs)," Journal of Hazardous Materials, vol. 172, pp. 532-549, 2009.

[2] A. Retnam, M. P. Zakaria, H. Juahir, A. Z. Aris, M. A. Zali, and M. F. Kasim. (2013). Chemometric techniques in distribution, characterization and source appointment of polycyclic aromatic hydrocarbons (PAHs) in aquaculture sediments in Malaysia. Marine Pollution Bulletin. [Online]. Available: http://dx.doi.org/10.1016/ j.marpolbul.2013.01.009.

[3] Y. Liu, L. Chen, Q. H. Huang, W. Y. Li, Y. J. Tang, and J. F. Zhao, "Source appointment of polycyclic aromatic hydrocarbons (PAHs) in surface sediments of the Hangpu river, Shanghai," Science of the Total Environment, vol. 407, pp. 2931-2938, 2009.

[4] M. P. Zakaria, H. Takada, S. Tsutsumi, K. Ohno, J. Yamada, E. Kuono, and H. Kumata, "Distribution of polycyclic aromatic hydrocarbons (PAHs) in rivers and estuaries in Malaysia: a widespread input of petrogenic PAHs," Environmental Science \& Technology, vol. 36, pp. 1907-1918, 2002.

[5] A. B. Azizi, Z. M. Noor, A. T. d. S. Jaime, A. Noorlidah, and A. J. Adi, "Vermicomposting of sewage sludge by Lumbricus rubellus using spent mushroom compost as feed material: Effect on concentration of heavy metals," Biotechnology and Bioprocess Engineering, vol. 16, no. 5, pp. 1036-1043, 2011.

[6] A. B. Azizi, M. P. M. Lim, Z. M. Noor, and A. Noorlidah, "Vermiremoval of heavy metal in sewage sludge by utilising Lumbricus rubellus," Ecotoxicology and Environmental Safety, vol. 90, pp. 13-20, 2013.

[7] S. M. Contreras-Ramos, D. Alvarez-Bernal, and L. Dendooven, "Eisenia foetida increased removal of polycyclic aromatic hydrocarbons from soil," Environmental Pollution, vol. 141, pp. 396-401, 2006.

[8] G. Tripathi and P. Bhardwaj, "Comparative studies on biomass production, life cycles and composting efficiency of Eisenia foetida (Savigny) and Lampito mauritii (Kinberg)," Bioresource Technology vol. 92, pp. 275-278, 2004.

[9] S. M. Contreras-Ramos, D. Alvarez-Bernal, and L. Dendooven, "Removal of polycylic aromatic hydrocarbons from soil amended with biosolid or vermicompost in the presence of earthworms (Eisenia foetida)," Soil Biology \& Biochemistry, vol. 40, pp. 1954-1959, 2008.

[10] M. Schaefer, S. O. Petersen, and J. Filser, "Effects of Lumbricus terrestris, Allolobophora chlorotica and Eisenia foetida on microbial community dynamics in oil-contaminated soil," Soil Biology \& Biochemistry, vol. 37, pp. 2065-2076, 2005.

[11] E. Borràs, G. Caminal, M. Sarrà, and C. Novotný, "Effect of soil bacteria on the ability of polycyclic aromatic hydrocarbons (PAHs) removal by Trametes versicolor and Irpex lacteus from contaminated soil," Soil Biology \& Biochemistry, vol. 42, pp. 2087-2093, 2010.

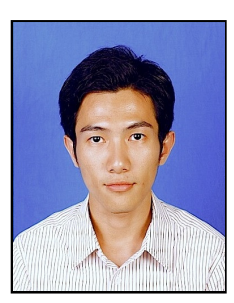

Azizi Abu Bakar was born in Perak, Malaysia on $9^{\text {th }}$ November 1987. This author became a Member of Japan Society for the Promotion of Science (JSPS)-Asian Core Program: Research and Education Center for the Risk Based Asian Oriented Integrated Watershed Management. He got his Bachelor (BSc) and Master of Science (MSc) from Environmental Science \& Management, University of Malaya, Kuala Lumpur, Malaysia 2009 and 2012. 
$\mathrm{He}$ is currently working with Sustainability Science (SuSci) Research Cluster under international collaboration, UM-Kyoto University Program at Research Management \& Innovation Complex (RMIC), University of Malaya, Kuala Lumpur, Malaysia as research officer. He has published articles in vermitechnology focusing on nutrient enrichment, heavy metal removal and degradation of persistent organic pollutant.

Mr. A. B. Azizi and research team won Gold Medal award in Innovation \& Creativitiy Expo '10, University of Malaya on the research: Recycling of spent mushroom compost via cutivation of snow pea sprouts (dou miao) artificial seeds and vermicomposting.

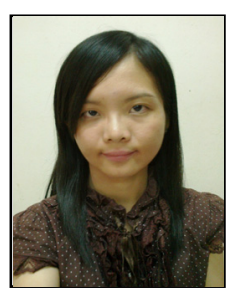

Liew Kar Yin was born in Kuala Lumpur, Malaysia on $9^{\text {th }}$ August 1988, and earned her bachelor's degree of Environmental Science \& Management from Institute of Biological Science, University of Malaya of Malaysia in 2011. She is currently working as QC/QA Executive in Shah Alam, Selangor, Malaysia.

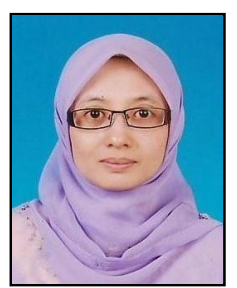

Noor Zalina Mahmood was born in Johore on $4^{\text {th }}$ January 1969. The author obtained her first degree in Ecology in 1993 form university of Malaya, Malaysia and completed her $\mathrm{PhD}$ in 2000 from University of Strathclyde, United Kingdom in Solid Waste Management.

She is currently a senior lecturer of Institute of Biological Sciences, Faculty of Science, University of
Malaya, Malaysia. She has involved with numerous research related to solid waste management and published journals.

Dr. Noor Zalina is also member of Japan Society for the Promotion of Science (JSPS)-Asian Core Program: Research and Education Center for the Risk Based Asian Oriented Integrated Watershed Management. She currently works on treatment and utilising waste such as agriculture waste, municipal and construction waste.

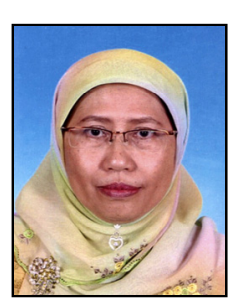

Noorlidah Abdullah had graduated in B.Sc (Medical Biochemistry) in 1984 from University of Surrey, United Kingdom, M.Sc. (Mycology) in 1989 and $\mathrm{Ph} . \mathrm{D}$ (Applied Mycology) in 1997 both from University of Malaya, Malaysia. She has contributed substantially to research, teaching and administration since she joined the Institute of Biological Sciences in 1997. Later she was promoted to Associate Professor in Oct 2002 and then Professor in 2008 and has become well known for her research in Fungal Biotechnology and Food Mycology.

She was given due recognition for her expertise in food mycology (mycotoxins) by the Ministry of Health for whom she has been an expert committee in Asean Expert Group On Food Safety and Food Additives and Contaminants Committee. She has published 70 articles in reputable journals and has supervised 48 postgraduate students. 